\title{
Nutritional Quality, Mycotoxins and Antinutritional Factors in Quality Protein Maize-Based Supplementary Foods for Children in Tanzania
}

\author{
Elina Maseta ${ }^{1,2}$, Theobald C.E. Mosha ${ }^{1}$, Henry Laswai1, Cornelio \\ N. Nyaruhucha ${ }^{1}$
}

${ }^{1}$ Department of Food Technology, Nutrition and Consumer Sciences, College of Agriculture, Sokoine University of Agriculture, P.O. Box 3006, Morogoro, Tanzania

${ }^{2}$ Department of Food and Nutrition, Open University of Tanzania, P.O. Box 23409, Dar es salaam, Tanzania

\begin{abstract}
Most complementary foods used for children in Tanzania are low in energy and nutrient content. In addition, they may contain contaminants such as mycotoxins and also antinutritional factors. The aim of this study was to determine nutritional quality of quality protein maize-based supplementary foods and levels of mycotoxins (fumonisins, aflatoxins) and antinutritional factors (phytates, tannins). Three composite diets were prepared from quality protein maize namely; quality protein maize-soybeans; quality protein maize-soybeans-common beans and quality protein maize-soybeans-cowpeas. The fourth and fifth diets were prepared from plain quality protein maize and plain common maize. The formulations were made to meet the greatest amino acid scores and the desired amount of energy and protein according to the FAO/WHO (1985) recommendation for pre-school children. Concentrations of energy, protein, amino acid, aflatoxins, fumonisins, phytates and tannins were determined by standard methods. Quality protein maize-soybeans-common beans and quality protein maize-soybeans-cowpeas met RDA for both energy (360 $\mathrm{kcal} / 100 \mathrm{~g}$ ) and protein (16 g/100 g) for children aged 2-5 years. The amino acid scores for QPM-based diets were higher than the recommended scores $(\geq 65 \%)$ for supporting optimal growth of children. Concentrations of fumonisin $\mathrm{B} 1$ and total fumonisin were 1687.82 and of $1717.16 \mu \mathrm{g} / \mathrm{kg}$ in quality protein maize and 1625.08 and $1745.22 \mu \mathrm{g} / \mathrm{kg}$ in plain common maize, respectively. These values were above the maximum tolerable limit of $1000 \mu \mathrm{g} / \mathrm{kg}$ recommended by the European commission. Efforts such as good agricultural practices and proper processing of food ingredients by sorting, dehulling and washing are recommended to reduce concentrations of fumonisins in maize grains.
\end{abstract}

Keywords: mycotoxins, soybeans, beans, cowpeas, tannin, phytate, extrusion-cooking, children, Tanzania

\section{Introduction}

Adequate nutrition and health care during the first several years of life is fundamental for child growth, development and survival. Although the causes of malnutrition are many and diverse, inadequate intake of foods and essential nutrients is a major contributory factor. At about six months of age, breast milk supply of energy and other nutrients such as proteins, vitamins and minerals is no longer adequate to meet child's body needs (WHO, 2009). Therefore, a high energy and nutrient dense complementary foods must be provided to the child. In many developing countries, Tanzania inclusive, cereals and legumes are used as a basis for these complementary foods (Kulwa et al., 2015). These foods are usually prepared as thin gruels. As a result, their energy and nutrient density are low. Furthermore, cereals and legumes are susceptible to fungal contamination. One of these contaminants is mycotoxins. Mycotoxins are fungal secondary metabolites produced by toxigenic strains of fungi that contaminate crops before or after harvest. The most common mycotoxin producing fungi belongs to the three genera of fungi: Aspergillus, Penicillium and Fusarium (Frisvad et al., 2006). Ingestion of mycotoxins contaminated grains by animals and human beings has enormous public health

This article is published under the terms of the Creative Commons Attribution License 4.0 Author(s) retain the copyright of this article. Publication rights with Alkhaer Publications. Published at: http://www.ijsciences.com/pub/issue/2016-07/

DOI: 10.18483/ijSci.1082; Online ISSN: 2305-3925; Print ISSN: 2410-4477 
significance, because these toxins are capable of causing diseases (Gnonlonfin et al., 2013). These toxins are nephrotoxic, immunotoxic, teratogenic and mutagenic. They are also capable of causing acute and chronic effects in man and animals ranging from disorders of the intestinal tract, central nervous, cardiovascular and pulmonary systems and death (Lombard, 2014). These mycotoxins have recently been associated with cancers and stunting in young children (IARC, 2016). The most toxic mycotoxins are aflatoxins, ochratoxin A, fumonisins, trichothecenes and zearalenone (Pitt, 2000).

Maize and beans are important food crops in Tanzania (Barreiro-Hurle, 2013 and ProFound, 2012). They are commonly used as ingredients in making complementary foods for children. Other cereals such as sorghum, rice, wheat and finger millet are rarely used. Apart from nuts, maize is more susceptible to mycotoxin contamination than any other crops. This is because corn production frequently encounters a period of drought and heat stress during flowering and kernel development. These weather conditions have been reported to increase mycotoxin contamination in maize than in other crops (Kebede et al., 2012). Maize contains about $45 \%$ carbohydrate, $5 \%$ protein and $2 \%$ fat in general (Enyisi et al., 2014). The protein content of beans ranges between $20-30 \%$ and $5 \%$ fat. Legumes are also rich in folate $(50 \%)$, and minerals such as iron (4\%), zinc (1\%), and calcium (24\%) (Messina, 1999). In addition to nutritional values of cereals and legumes, their use is limited due to presence of antinutritional factors. Phytic acid for example, reduces the availability of many minerals such as iron, zinc, calcium and magnesium (Asuquo \& Etim, 2011). Ability of phytate to form complexes with these minerals makes the minerals not bioavailable. Tannins are known to bind proteins, including digestive enzymes leading to poor protein digestibility (McSweeney et al., 2001). Formation of protein complexes lowers protein digestibility, hence reducing food utilization and growth in children. It is therefore recommended that, when preparing complementary foods for children various methods should be used in inactivating and/or reducing these antinutritional factors. In Tanzania, some efforts have been made to determine nutrient content, levels of mycotoxins and antinutritional factors in cereal-based complimentary foods for children in plain or composite maize with legumes and/or nuts (Kimanya et al., 2014: Magoha et al., 2014). There is however, limited information documented about mycotoxin and antinutritional factors in quality protein maize (QPM)based formulations for children in Tanzania although QPM use has been growing steadily in the past decade. This study was carried out to determine the nutritional quality, mycotoxins (aflatoxin and fumonisin) and antinutritional factors (phytate and tannins concentrations) in QPM-based composite formulations used for supplementing children in Tanzania.

\section{Materials and Methods \\ Materials}

Quality protein maize was purchased from Seliani Research Station in Arusha, Tanzania. Common maize (Zea mays), soybeans (Glycine max), common beans (Phaseolus vulgaris), cowpeas (Vigna unguiculata), edible vegetable oil and sugar were purchased from Morogoro Municipal central market.

\section{Product Formulation and Processing Blend formulation}

Formulations of high-protein-energy supplementary foods were made to meet the greatest amino acid score and the desired amount of energy and fat according to the FAO/WHO (1985) Codex Alimentarius guidelines for supplementary foods for infants and young children. The blend ratios of QPM, soybean, common beans, cowpeas and normal maize are shown in Table 1.

Table 1: Composition of the maize-based supplementary food formulations

\begin{tabular}{|c|c|c|c|c|c|}
\hline \multirow[b]{2}{*}{ Ingredient } & \multicolumn{5}{|c|}{ Formulations $^{1}(\mathrm{~g} / 100 \mathrm{~g})$} \\
\hline & QS & QSC & QSB & QQ & $\mathrm{CM}$ \\
\hline QPM & 68 & 46 & 45 & 82 & - \\
\hline Soybean & 14 & 6 & 7 & - & - \\
\hline Cowpeas & - & 30 & - & - & - \\
\hline Common beans & - & - & 30 & - & - \\
\hline Common maize & - & - & - & - & 82 \\
\hline Cooking oil & 10 & 10 & 10 & 10 & 10 \\
\hline Multi-mix ${ }^{2}$ & 3 & 3 & 3 & 3 & 3 \\
\hline Sugar & 5 & 5 & 5 & 5 & 5 \\
\hline Total & 100 & 100 & 100 & 100 & 100 \\
\hline
\end{tabular}


${ }^{1} \mathrm{QS}=\mathrm{Quality}$ protein maize-Soybean; $\quad$ QCS=Quality protein maize-Cowpeas-Soybean: QBC=Quality protein maize-common Beans -Soybean $\mathrm{QQ}=\mathrm{Quality}$ protein maize; $\mathrm{CM}=$ Common Maize

\section{Food processing}

Separately, QPM, common maize (CM), soybeans, common beans and cowpeas were sorted to remove extraneous materials and pebbles and washed twice in distilled water. Then, QPM and CM were separately dehulled. Thereafter, each of these ingredients was separately milled into fine flour (mesh size $0.4 \mathrm{~mm}$ ) using a commercial hammer mill (Intermek, Tanzania) to fine flour. Three formulations were developed; QPM-Soybeans (QS), QPM-soybeans-common beans (QSB) and QPM-soybeans-cowpeas (QSC). The fourth product was made from QPM alone (QQ) and fifth products from common maize alone (CM). Each food product was conditioned to $22 \%$ moisture content and 5\% vegetable oil and allowed to equilibrate for 30 minutes. The food mixtures were separately extruded using a commercial twin-screw extruder (Model JS 60 D, Qitong Chemical Industry Equipment Co. Ltd, Yantai, China) with two electrically heated zones. The following extrusion conditions were adopted: Temperatures $130^{\circ} \mathrm{C}$ (Zone 1) and $122^{\circ} \mathrm{C}$ (Zone 2), main motor speed was set at $10.48 \mathrm{rpm}$ and feeder speed at $10.26 \mathrm{rpm}$. Desired barrel temperature was maintained by circulating cold water. Temperature was controlled by inbuilt thermostat and a temperature control unit. The extruder was cleaned after each run with moist maize flour. After extrusion, the extrudates were allowed to cool and dry at room temperature, thereafter milled, fortified and packaged in polyethylene packets ready for laboratory analysis.

\section{Chemical Assays}

Crude protein, energy and amino acid determination Crude protein was determined according to AOAC (1995). Carbohydrate content was calculated by difference. Energy values (kcal) were calculated by using Atwater conversion factors 4, 9 and 4 for each gram of protein, fat and carbohydrate, respectively (AOAC, 1995). Amino acid concentrations (except tryptophan) were determined by a high performance liquid chromatography using the Waters Pico-Tag method (Cohen et al., 1989). For all amino acids except methionine, cysteine and tryptophan, food samples were hydrolysed in $6 \mathrm{~N} \mathrm{HCl}$. The methionine and cysteine in foods were oxidised by performic acid to methionine sulfone and cysteic acid prior to hydrolysis by $6 \mathrm{~N} \mathrm{HCl}$. All amino acids (except tryptophan) were derivatised by phenyl isothiocayanate and detected at $254 \mathrm{~nm}$. Tryptophan was analysed by ion exchange chromatographic method as described in the AOAC (1995) method 988.15. The protein in the food was hydrolysed under vacuum with $4.2 \mathrm{~N} \mathrm{NaOH}$. After $\mathrm{pH}$ adjustment and clarification, tryptophan was separated by ion exchange chromatography (DC5A cation exchange resin) with measurement of the ninhydrinchromophore.

\section{Amino acid score}

The amino acid score was calculated using the ratio of a gram of the limiting amino acid of test diet to the same amount of the corresponding amino acid in the reference protein multiplied by 100 . The reference proteins suggested by FAO/WHO/UNU (1985) for children aged 2-5 years was used for calculating amino acid score.

\section{Aflatoxins and fumonisins determination}

Aflatoxin concentration was determined according to method described by Kimanya et al. (2008). Determination of fumonisins B1 and fumonisins B2 was carried out using HPLC method described by Samapundo et al. (2006) and Kimanya et al. (2008). Phytic acid concentration was determined by the method described by Wheeler and Ferrel (1971). Tannin was determined following the method described by Porter et al. (1986).

\section{Statistical analysis}

All data (except for amino acids), were subjected to analysis of variance (ANOVA) using Genstat (1998, version 4). For amino acids, mean values were computed. The concentrations of mycotoxin and antinutritional factors in the composite products were compared by using the Turkeys Least Significant Difference (LSD) test when difference existed. Differences were considered significant at $\mathrm{p} \leq 0.05$.

\section{Results and Discussion \\ Energy, protein content and amino acid profile of QPM-based composite foods}

Chemical assays showed an increase in protein content of the composite diets blended with soybeans. The energy and protein density of the diets were $386 \mathrm{kcal}$ and $17 \mathrm{~g}$ per $100 \mathrm{~g}$ of QSB, $389 \mathrm{kcal}$ and $16 \mathrm{~g}$ per 100 $\mathrm{g}$ of QSC, $381 \mathrm{kcal}$ and $16 \mathrm{~g}$ per $100 \mathrm{~g}$ of QS,387 kcal and $6 \mathrm{~g}$ per $100 \mathrm{~g}$ of CM. Comparing with FAO/WHO reference, diets QSB and QSC met both energy (360 $\mathrm{kcal})$ and protein content (16 g) per $100 \mathrm{~g}$ of edible food required for children aged 2-5 years. This could partly be attributed to the higher contents of protein supplemented to QPM blended flour. These findings were in line with those reported by other investigators (Madukwe et al., 2013: Kadam et al., 2012). Consumption of cereal based supplementary food with other protein rich diet is of great nutritional benefit since nutrient complementarity can be achieved. Mohsen et al. (2009) reported contrasting findings indicating that soybean supplementation did not improve the protein composition of wheat cookies. From this study, carbohydrate content decreased from 
90.5 and $88.7 \%$ in plain CM and plain QPM products, respectively, to 79, 79 and $81 \%$ in QS, QSB and QSC diets, respectively. This decrease could be explained by the low carbohydrate content of legumes, soybean, common beans and cowpeas (Nwosu 2013: Khan, 2009). Soybean stores energy at approximately $21 \%$ fat and $4 \%$ crude fibre, whereas maize stores $73 \%$ energy as carbohydrate (starch) (Rajendar et al., 2013). Therefore, blending maize with soybean diluted the carbohydrate concentrations of the composite products.

Amino acid profiles of the experimental and control diets are presented in Table 2. Amino acid composition of the composite diets ranged between 15 $\mathrm{mg} / 100 \mathrm{~g}$ for tryptophan (QQ diet) and $109 \mathrm{~g} / 100 \mathrm{~g}$ for leucine (CM diet). Lysine and tryptophan contents of the composite diets increased with soybean supplementation. Lysine content in QPM-based diets ranged from 67 to $74 \mathrm{mg} / 100 \mathrm{~g}$ protein in QS and QSB, respectively. Tryptophan concentration ranged from 16 to $18 \mathrm{mg} / 100 \mathrm{~g}$ protein in QS and QSB, respectively. Lysine and tryptophan contents of QSB and QSC were higher than the levels in reference protein for children aged 2-5 years $(58 \mathrm{mg} / \mathrm{g}$ Lys and $11 \mathrm{mg} / \mathrm{g}$ Trp) (FAO/WHO/UNU, 1985). Plain common maize diet (CM) contained lower concentration of lysine and tryptophan than the recommended levels of Lys $(58 \mathrm{mg} / \mathrm{g})$ and Trp (11 $\mathrm{mg} / \mathrm{g}$ ) protein, for children $2-5$ years. This study revealed that, histidine, threonine, valine, leucine, lysine, tryptophan, sulphur containing amino acids (methionine and cysteine) and aromatic amino acids (phenylalanine and tyrosine) were present in adequate amounts in the QPM-based diets when compared with the recommended levels for children 2-5 years by (FAO/WHO/UNU 2002). Amino acid that is in short supply is referred to as the most limiting amino acid (Häffner et al., 2003). Results of amino acid score in the test diets indicated that lysine was the most limiting amino acids in all the diets. This observation was in agreement with (Caire-Juvera et al., 2013) (Nuss \& Tanumihardjo, 2011) and (Häffner et al., 2003) who reported lysine as the most limiting amino acid in cereals. Amino acid scores for the QPM-based diets were higher than the minimum value $(\geq 65 \%)$ recommended by the FAO/WHO/UNU (1985) Codex Alimentarius for children aged 2-5 years. This could be attributed to the inclusion of soybeans which improved their amino acid profile. Common maize was the only diet with limiting amino acid less than the recommended value of $\geq 65 \%$. Several studies have shown that, common maize is limiting in lysine and tryptophan (Nuss \& Tanumihardjo, 2011; Sofi et al., 2009).

Table 2: Amino acid profile and scores of the various foods designed for children aged 2-5 years

\begin{tabular}{lllllllllll}
\hline & CM & AAS & QS & AAS & QQ & AAS & QSB & AAS & QSC & AAS \\
\hline Amino acid (mg/g) & & & & & & & & & \\
Histidine & 31 & 162 & 36 & 189 & 41 & 216 & 34 & 179 & 37 & 195 \\
Threonine & 29 & 85 & 43 & 126 & 41 & 121 & 44 & 129 & 43 & 126 \\
Valine & 45 & 128 & 59 & 169 & 60 & 171 & 58 & 166 & 59 & 169 \\
Leucine & 121 & 184 & 103 & 156 & 106 & 161 & 96 & 145 & 98 & 148 \\
Lysine & 26 & 45 & 67 & 116 & 50 & 86 & 74 & 128 & 73 & 126 \\
Tryptophan & 7 & 67 & 16 & 145 & 15 & 136 & 18 & 164 & 17 & 155 \\
SAA & 41 & 165 & 37 & 148 & 46 & 184 & 44 & 176 & 42 & 168 \\
AAA & 76 & 120 & 91 & 144 & 73 & 116 & 91 & 144 & 88 & 140 \\
Limiting & & Lys & & Lys & & Lys & & Lys & & Lys \\
AA & & & & & & & & & & \\
\hline
\end{tabular}

${ }^{\mathrm{a}} \mathrm{CM}=$ Common maize: $\mathrm{QS}=$ Quality protein maize- Soy bean: $\mathrm{QQ}=$ Quality protein maize: $\mathrm{QSB}=\mathrm{Quality}$ protein maize-Soy bean-common Bean: QSC= Quality protein maize-Soy bean-Cow peas: $\mathrm{SAA}=$ sulphur containing amino acid (methionine and cysteine): $\mathrm{AAA}=$ aromatic amino acids (phenylalanine and tyrosine)

$\mathrm{AAS}=$ Amino acid Score

Mycotoxin contamination of the composite diets

Aflatoxins and fumonisins concentrations of the various food samples are summarized in Table 3. Concentrations of aflatoxin B1 and total aflatoxins in all the food samples were less than one microgram per kilogram. These concentrations were far below the Tanzania recommended concentrations of $5 \mu \mathrm{g} / \mathrm{kg}$ for aflatoxin B1 and $10 \mu \mathrm{g} / \mathrm{kg}$ for total aflatoxin in supplementary foods for children (Tanzania Bureau of Standards, 2010). Likewise, the European Commission (2006) recommends the upper limits of 2 $\mu \mathrm{g} / \mathrm{kg}$ aflatoxin B1 and $4 \mu \mathrm{g} / \mathrm{kg}$ (total aflatoxin) for foodstuffs. High aflatoxin contaminations in maize has been reported in Tanzania recently (Gheysens, 2015). 
According to Gheysens (2015), aflatoxin B1 concentration in samples of maize collected in rural Tanzania was $94.23 \mu \mathrm{g} / \mathrm{kg}$ while total aflatoxin concentration was $219.45 \mu \mathrm{g} / \mathrm{kg}$. A study by Kumi (2014) in Ghana reported mean total aflatoxin contamination of $145.2 \mu \mathrm{g} / \mathrm{kg}$ in weanmix. In a recent study in Tanzania (Kamala et al., 2016), 45\% of the maize samples evaluated were contaminated with aflatoxins with levels ranging from 0.1 to $269 \mu \mathrm{g} / \mathrm{kg}$. Low levels of total and aflatoxin B1 observed in the current study might be due to the processes that were made on the maize before extrusion. Maize and legumes that were used in this study were washed and dehulled. These processes have been reported to reduce mycotoxin levels. Fandohan et al.(2005) reported that, processing methods such as sorting, winnowing, washing and dehulling of maize grains removed up to $93 \%$ of aflatoxin and $48 \%$ of fumonisins.

This study showed that plain maize diets (QQ and CM) had higher levels of fumonisin contamination than blended diets. Diet QQ had fumonisins B1 concentrations of $1687.82 \mu \mathrm{g} / \mathrm{kg}$ and total fumonisins concentrations of $1717.16 \mu \mathrm{g} / \mathrm{kg}$, whereas diet $\mathrm{CM}$ had fumonisin B1 concentrations of $1625.08 \mu \mathrm{g} / \mathrm{kg}$ and total fumonisins concentrations of $1745.22 \mu \mathrm{g} / \mathrm{kg}$. These two diets, QQ and CM were the only samples with fumonisins concentrations above the upper limit of $1000 \mu \mathrm{g} / \mathrm{kg}$ recommended by the European commission (EC, 2006). Fumonisin B1 and total fumonisins levels reported in this study were lower than levels reported from other studies conducted in Tanzania. A recent study by Gheysens (2015) in rural Tanzania reported values of fumonisin B1 and total fumonisin higher than those observed in this study.

According to Gheysens (2015), concentrations of mycotoxins in maize grains were fumonisn B1 $(0.00$ $5461.00 \mu \mathrm{g} / \mathrm{kg})$, fumonisin B2 $(0.00-1756.80 \mu \mathrm{g} / \mathrm{kg})$ and total fumonisins $(0.00-6761.00 \mu \mathrm{g} / \mathrm{kg})$. The maize used for their study were just crushed prior to analysis of mycotoxins unlike the maize grains used in our study which were sorted, winnowed, washed, dehulled, milled and extruded before analysis. These processes were missing in the Gheysens (2015) study. Magoha et al. (2014) reported that $68 \%$ of the flour samples collected from Northern Tanzania were contaminated with total fumonisin concentration above the maximum tolerable limit (MTL). A study by (Kumi et al., 2014) in weanmix observed that, mean fumonisin contamination was $4.6 \mu \mathrm{g} / \mathrm{kg}$ in the composite flour. Furthermore, $58.3 \%$ of the weanmix samples were contaminated with fumonisin concentration above the U.S. FDA limit of $4 \mu \mathrm{g} / \mathrm{kg}$. Chronic mycotoxin exposure has major effects on nutritional status in human. It suppresses body's immunity and nutritional status. Aflatoxin B1 is known to be acutely toxic and a cause of liver cancer in humans (Shephard, 2008). Aflatoxin exposure has also been associated with an increased risk for liver cirrhosis (Kuniholm et al., 2008). Fumonisin and aflatoxin exposure early in life has been associated with impaired growth, particularly stunting in Tanzania (Kimanya 2010) and West Africa (Gong et al., 2003).

\section{Antinutritional factors of the formulated diets}

Concentrations of phytate and tannin in the composite foods are presented in Table 3. Concentrations of phytic acid among the food products were significantly different $(\mathrm{p}<0.05)$, increasing with the level of legume substitution (16.6 to $24.6 \mathrm{mg} / 100 \mathrm{~g}$ ). The concentrations of phytates in the supplementary foods studied were lower than $25 \mathrm{mg} / 100 \mathrm{~g}$, the amount considered lethal to health (Nagel, 2010). Similarly, tannin levels increased with legume supplementation. Tannins concentrations were very low (0.12-3.5 $\mathrm{mg} / 100 \mathrm{~g}$ ) while the reported lethal dose is $90 \mathrm{mg} / 100 \mathrm{~g}$ (Ifie \& Emeruwa, 2011). This indicated that, the concentrations of phytates and tannins in the composite diets were of acceptable safe levels and the foods were therefore safe for human consumption. According to Kumaret al. (2010), high levels of phytates in human foods limits the bioavailability and hence utilization of minerals, specifically calcium, magnesium, iron and manganese by forming insoluble compounds that are indigestible. These minerals play important roles in children bodies by supporting growth, bone and tissue development. Observed low phytate in extruded diets might be associated with heat treatment which is known to reduce concentrations of antinutritional factors. Processes such as extrusion have been reported to destroy antinutritional factors and inactivated lipoxygenase enzyme responsible for the beany flavour development. Beany flavor has been reported to adversely affect utilization of legumes in foods. Several authors have reported on the effects of extrusion on inactivating antinutritional factors; phytic acid in soybean (Ariet et al., 2012), cowpeas (Olapade \& Umeonuorah, 2013: Olapade \& Aworh, 2012), trypsin inhibitor activity in pinto beans (BalandranQuintana et al.,1998) and phytic acid in pigeon pea (Anuonye et al.,2012). A study by (Anton et al. (2009) reported that, extrusion cooking reduced phytic acid inhibitor levels to nearly $50 \%$ in maize-common bean blend. Concentrations of phytates and tannins observed in this study posed no health risk to the consumers. 
Table 3: Concentrations of aflatoxins, fumonisins and antinutritional factors in the various food formulations

\begin{tabular}{|c|c|c|c|c|c|c|c|c|c|c|}
\hline \multirow[b]{3}{*}{ Diet } & \multicolumn{8}{|c|}{ Mycotoxins $(\mu \mathrm{g} / \mathrm{kg})$} & \multirow{2}{*}{\multicolumn{2}{|c|}{$\begin{array}{c}\text { Antinutrients } \\
(\mathrm{mg} / \mathbf{1 0 0} \mathrm{g})\end{array}$}} \\
\hline & \multicolumn{5}{|c|}{ Aflatoxins } & \multicolumn{3}{|c|}{ Fumonisins } & & \\
\hline & B1 & B2 & $\mathbf{G}_{1}$ & $\mathbf{G}_{2}$ & Total & B1 & B2 & Total & Phytates & Tannin \\
\hline $\mathrm{CM}$ & $0.15^{\mathrm{d}}$ & $0.02^{\mathrm{a}}$ & $0.07^{\mathrm{d}}$ & $0.07^{\mathrm{a}}$ & $0.66^{\mathrm{a}}$ & $1625.08^{b}$ & $120.22^{\mathrm{a}}$ & $1745.22^{\mathrm{b}}$ & $16.61^{\mathrm{d}}$ & $0.12^{\mathrm{a}}$ \\
\hline QS & $0.23^{\mathrm{c}}$ & ND & $0.01^{\mathrm{d}}$ & $0.02^{\mathrm{a}}$ & $0.26^{\mathrm{a}}$ & $112.60^{\mathrm{e}}$ & $86.29^{\mathrm{b}}$ & $198.89^{\mathrm{e}}$ & $22.63^{c}$ & $0.56^{\mathrm{ab}}$ \\
\hline QQ & $0.33 b$ & ND & $0.02^{\mathrm{d}}$ & $0.05^{\mathrm{a}}$ & $0.40^{\mathrm{a}}$ & $1687.82^{\mathrm{a}}$ & $29.34^{\mathrm{c}}$ & $1717.16^{\mathrm{a}}$ & $17.54^{\mathrm{d}}$ & $0.23^{c}$ \\
\hline QSB & $0.50^{\mathrm{a}}$ & ND & $0.05^{\mathrm{ab}}$ & ND & $0.55^{\mathrm{a}}$ & ND & ND & ND & $24.62^{c}$ & $3.45^{\mathrm{d}}$ \\
\hline QSC & $0.50^{\mathrm{a}}$ & $0.11^{\mathrm{a}}$ & ND & $0.05^{\mathrm{a}}$ & $0.56^{\mathrm{a}}$ & $330.72^{\mathrm{d}}$ & ND & $330.72^{\mathrm{d}}$ & $22.93^{\mathrm{b}}$ & $2.74^{\mathrm{e}}$ \\
\hline LSD & 0.04 & 0.00 & 0.03 & 0.06 & 0.07 & 4.631 & 0.115 & 4.634 & 6.612 & 0.7278 \\
\hline
\end{tabular}

*Mean values in a column with different super script are significantly different at $\mathrm{p}<0.05$ : ND= Not Detected

\section{Conclusion and Recommendations}

Supplementation of plain maize flour with soybeans, common beans and cowpeas increased the energy density and protein content. Lysine and tryptophan contents of QSB and QSC diets were higher than the FAO/WHO/UNU (1985) recommended levels for children aged 2-5 years. The amino acid scores for QPM-based diets were higher than the recommended scores of $\geq 65 \%$ needed for supporting optimal growth of children aged 2-5 years. Diets QSB and QSC had both aflatoxin and fumonisin concentrations below the maximum tolerable limits set by Tanzania Bureau of Standards and European Commission. Conversely, both CM and QQ diets had higher concentrations of fumonisin above the maximum tolerable limits set by Tanzania Bureau of Standards and European Commission. Based on these results, it is recommended that efforts must be made to reduce the levels of fumonisins in maize grain. This can be achieved through good agricultural practices and proper processing practices of food ingredients such as sorting, dehulling and washing when making supplementary foods for children.

\section{Conflict of interests}

The authors declare that they have no conflict of interest.

\section{Acknowledgements}

The authors thank The World Bank and The Open University of Tanzania for financial support to undertake this study.

\section{References}

1) AOAC (1995). Official Methods of Analysis. 16th Edition. Association of Official Analytical Chemists, Washington, D. C, USA

2) Anton, A. A., Gary Fulcher, R. and Arntfield, S. D. (2009). Physical and nutritional impact of fortification of corn starch-based extruded snacks with common bean (Phaseolus vulgaris L.) flour: Effects of bean addition and extrusion cooking. Food Chemistry, 113(4): 989-996. http://doi.org/10.1016/j.foodchem.2008.08.050
3) Anuonye, J. C., Jigam, A. A. and Ndaceko, G. M. (2012). Effects of extrusion-cooking on the nutrient and antinutrient composition of pigeon pea and unripe plantain blends. Journal of Applied Pharmaceutical Science, 2(5): 158-162. http://doi.org/10.7324/JAPS.2012.2533

4) Ari, M., Ayanwale, B., Adama, T. and Olatunji, E. (2012). Evaluation of the chemical composition and antinutritional factors (ANFs) levels of different thermally processed soybeans. Asian Journal of Agricultural Research

5) Asuquo, J. E. and Etim, E. E. (2011). Phytochemical and antinutrients evaluation of Oxyporus Populinus. Journal of Emerging Trends in Engineering and Applied Sciences, 2(5), 817-820. Retrieved from http://reference.sabinet.co.za/webx/access/electronic_journ als/s1_jeteas/s1_jeteas_v2_n5_a17.pdf

6) Balandran-Quintana, R. R., Barbosa-Canovas, G. V., Zazueta-Morales, J. J., Anzaldua-Morales, A and QuinteroRamos, A (1998). Functional and Nutritional Properties of Extruded Whole Pinto Bean Meal (Phaseolus Vulgaris L.). Journal of Food Science, 63(1): 113-116. http://doi.org/10.1111/j.1365-2621.1998.tb15688.x

7) Barreiro-Hurle, J. (2013). Analysis of Incentives and Disincentives for Maize in the United Republic of Tanzania. Technical notes series. MAFAP, FAO, Rome.

8) Caire-Juvera, G., Vázquez-Ortiz, F. a, \& Grijalva-Haro, M. I. (2013). Amino acid composition, score and in vitro protein digestibility of foods commonly consumed in northwest Mexico. Nutrición Hospitalaria, 28(2), 365-71. http://doi.org/10.3305/nh.2013.28.2.6219

9) Cohen, S.A., Meys, M. and Tarwin, T.L.(1989). The Pico Tag method: a manual of advanced techniques for amino acid analysis, Rev. 1.Bedford (MA): Millipore.

10) Enyisi, S., Umoh, V. J., Whong, M. Z., Abdullahi, O. and Alabi, O. (2014). Chemical and nutritional value of maize and maize products obtained from selected markets in Kaduna. African Journal of Food Science and Technology, 5(4): 100-104.

11) Erdman, J. W., Jr. (1979) Oilseed phytates: nutritional implications. Journal of the American Oil Chemists' Society. 56: 736-741.

12) European Commission (EC), (2006). Commission Regulation (EC) No 1881/2006 of 19 December 2006 setting maximum levels for certain contaminants in foodstuffs. Official Journal of the European Union, 364: 524.

13) Fandohan, P, Zoumenou, D, Hounhouigan, D.J, Marasas, W.F.O., Wingfield, M.J. and Hell, K. (2005). Fate of aflatoxins and fumonisins during the processing of maize into food products in Benin. International Journal of Food Microbiology, 98: 249-259. http://doi.org/10.1016/j.ijfoodmicro.2004.07.007

14) FAO/WHO/UNU (1985). Energy and Protein 
Requirements. Report of a Joint FAO/WHO/UNU Expert Consultation. WHO Technical Report Series No. 724. WHO, Geneva. 207pp.

15) Fasuyi, A.O. (2005). Nutrient Composition and Processing Effects on Cassava Leaf Manihot esculenta, Crantz) Antinutrients. Pakistan Journal of Nutrition. 4 (1): 37-42.

16) Frisvad, J.C., Thrane, U., Samson, R.A. and Pitt, J.(2006). Important mycotoxins and the fungi which produce them. In: Hocking AD, Pitt JI, Samson RA, Thrane U eds. Advances in food mycology. New York: Springer: 3-31. http://doi.org/10.1017/CBO9781107415324.004.

17) Gheysens, E. (2015). Influence of changed complementary food composition on exposure to aflatoxins and fumonisins for infants in rural Tanzania. Univerity of Ghent.

18) Gnonlonfin, G. J. B., Hell, K., Adjovi, Y., Fandohan, P., Koudande, D. O., Mensah, G. A., Sanni, A. and Brimer, L. (2013). A Review on Aflatoxin Contamination and Its Implications in the Developing World: A Sub-Saharan A Review on Aflatoxin Contamination and Its Implications in the Developing World : A Sub-Saharan. Critical Reviews in Food Science and Nutrition, 53: 349-365. http://doi.org/10.1080/10408398.2010.535718

19) Gong, Y. Y., Egal, S., Hounsa, A., Turner, P. C., Hall, A. J., Cardwell, K. F., \& Wild, C. P. (2003). Determinants of aflatoxin exposure in young children from Benin and Togo, West Africa: The critical role of weaning. International Journal of Epidemiology, 32(4), 556-562. http://doi.org/10.1093/ije/dyg109

20) Häffner, J., Kahrs, D., Limper, J., De Mol, J., Peisker, M., \& Williams, P. (2003). Amino Acids in Animal Nutrition. AGRIMEDIA. http://doi.org/10.1079/9780851996547.0000

21) IARC. (2015). New IARC report urges action against widespread mycotoxin contamination in developing countries. IDRC, France.

22) Ifie, I. and Emeruwa, C. (2011). Nutritional and antinutritional characteristics of the larva of Oryctes monoceros. Agriculture and Biology Journal of North America, (1992): 42-46. http://doi.org/10.5251/abjna.2011.2.1.42.46

23) Kamala, A., Kimanya, M., Haesaert, G,. Tiisekwa, B,., Madege, R,. Degraeve, S,. Cyprian, C. and De Meulenaer, B (2016). Local post-harvest practices associated with aflatoxin and fumonisin contamination of maize in three agro ecological zones of Tanzania. Food additives \& contaminants. Part A, Chemistry, analysis, control, exposure \& risk assessment 33(3):551-9.

24) doi: 10.1080/19440049.2016.1138546.

25) Khan, M. I. (2009). Utilization of soybean as a functional food. Thesis for Award of PhD Degree at University of Agriculture Faisalabad.

26) Kimanya, M., De Meulenaer, B.,Tiisekwa, B., NdomondoSigonda, M., \& Kolsteren, P. (2008). Human exposure to fumonisins from home grown maize in Tanzania. World Mycotoxin Journal, 1(3), 307-313

27) Kimanya, M.E, De Meulenaer, B, Roberfroid, D., Lachat,D and Kolsteren, P (2010). Fumonisin exposure through maize in complementary foods is inversely associated with linear growth of infants in Tanzania. Mol Nutr Food Res 54(11):1659-67

28) Kimanya, M. E., Shirima, C. P., Magoha, H., Shewiyo, D. H., De Meulenaer, B., Kolsteren, P. and Yun, Y. (2014). Coexposures of a $\mathrm{fl}$ atoxins with deoxynivalenol and fumonisins from maize based complementary foods in Rombo , Northern Tanzania. Food Control, 41, 76-81. http://doi.org/10.1016/j.foodcont.2013.12.034

29) Kulwa, K. B. M., Mamiro, P. S., Kimanya, M. E., Mziray, R., \& Kolsteren, P. W. (2015). Feeding practices and nutrient content of complementary meals in rural central Tanzania : implications for dietary adequacy and nutritional status. BMC Pediatrics, 15(171), 1-11. http://doi.org/10.1186/s12887-015-0489-2

30) Kumar, V., Sinha, A. K., Makkar, H. P. S. and Becker, K.
(2010). Dietary roles of phytate and phytase in human nutrition: A review. Food Chemistry, 120, 945-959. http://doi.org/10.1016/j.foodchem.2009.11.052

31) Lombard, M. J. (2014). Infants and children are especially vulnerable to mycotoxin exposure, mostly because of a lower detoxification capacity, rapid growth and high intake of food and water per kg body weight. Mycotoxin Exposure and Infant and Young Child Growth in Africa: Annals of Nutrition \& Metabolism, 64(2): 42-52. http://doi.org/10.1159/000365126

32) Magoha, H., Kimanya, M., De Meulenaer, B., Roberfroid, D., Lachat, C. and Kolsteren, P. (2014). Original Article Risk of dietary exposure to aflatoxins and fumonisins in infants less than 6 months of age in Rombo, Northern Tanzania. Maternal and Child Nutrition. http://doi.org/10.1111/mcn.12155

33) Mamiro, P.S., Kolsteren, P.W., Van Camp, J.H., Roberfroid, D.A., Tatala, S. and Opsomer. A.S (2004). Processed complementary food does not improve growth or hemoglobin status of rural Tanzanian infants from 6-12 months of age in Kilosa District, Tanzania. Journal of Nutrition, 134:1084-90.

34) McSweeney, C. S., Palmer, B., McNeill, D. M. and Krause, D. O. (2001). Microbial interactions with tannins: Nutritional consequences for ruminants. Animal Feed Science and Technology, 9: 83-93. http://doi.org/10.1016/S0377-8401(01)00232-2

35) Messina, M. J. (1999). Legumes and soybeans: Overview of their nutritional profiles and health effects. American Journal of Clinical Nutrition, 1999;70(suppl):439S-50S.

36) Nagel, R. (2010). Living With Phytic Acid. Wise Traditions in Food, Farming and the Healing Arts, the quarterly journal of the Weston.

37) Nuss, E. T., \& Tanumihardjo, S. A. (2011). Quality Protein Maize for Africa : Closing the Protein Inadequacy Gap in Vulnerable Populations 1, 2. Advanced Nutrition, (3), 217224. http://doi.org/10.3945/an.110.000182

38) Nwosu J.N. (2013). Production and Evaluation of Biscuits from Blends of Bambara Groundnut ( Vigna Subterranae ) and Wheat ( Triticum Eastrum ) Flours. International Journal of Food and Nutrition Science Vol2 No1, 2(March).

39) Olapade, A. A and Aworh, O. C. (2012). Chemical and Nutritional Evaluation of Extruded Complementary Foods from Blends of Fonio ( Digitaria Exilis Stapf ) and Cowpea ( Vigna Unguiculata L. Walp ) Flours. International Journal of Food and Nutrition Science, 1(3): 4-8.

40) Olapade, A. A . and Umeonuorah, U. C. (2013). Mineral, Vitamin and Antinutritional Content of African Breadfruit ( Treculia africana ) Seeds Processed with Alum and Trona. IOSR Journal Of Environmental Science, Toxicology And Food Technology, 5(5): 71-78.

41) Osuret, J., Musinguzi, G., Mukama, T., Halage, A. A., Natigo, A. K., Ssempebwa, J. C and Wang, J. (2016). Aflatoxin Contamination of Selected Staple Foods Sold for Human Consumption in Kampala Markets , Uganda. Journal of Biological Sciences, 16: 44-48. http://doi.org/10.3923/jbs.2016.44.48

42) Pitt, J. I. (2000). Toxigenic fungi and mycotoxins. British Medical Bulletin, 56(1): 184-192

43) Porter, L.J., Hrstich, L.N. and Chan, B.G. (1986). The conversion of procyanidins and prodelphinidins to cyanidins and delphinidins. Phytochemistry 25, 223-230

44) ProFound. (2012). Organic Kidney Beans: Potential for Certified Producers in Tanzania. Belgian Development Agency, Brussels.

45) Raihanatu, M. B., Modu, S., Falmata, a S., Shettima, Y. A. and Heman, M. (2011). Effect of processing ( sprouting and fermentation ) of five local varieties of sorghum on some biochemical parameters. Biokemistri, 23(2): 91-96.

46) Samapundo, S., De Meulenaer, B., De Muer, N., Debevere, J. and Devlieghere, F. (2006) Influence of experimental parameters on the fluorescence response and recovery of the high-performance liquid chromatography analysis of 
fumonisin $\mathrm{B}_{1}$. Journal of Chromatography. A 1109, 312316.

47) Shephard, G. S., Marasas, W. F. O., Burger, H.-M., Somdyala, N. I. M., Rheeder, J. P., Van der Westhuizen, L., Gatyeni, P and Van Schalkwyk, D. J. (2007). Exposure assessment for fumonisins in the former Transkei region of South Africa. Food Additives and Contaminants, 24(6): 621-629. http://doi.org/10.1080/02652030601101136

48) Sofi, P. A., Wani, S. A., Rather, A. G., \& Wani, S. H. (2009). Review article: Quality protein maize ( QPM ): Genetic manipulation for the nutritional fortification of maize. Journal of Plant Breeding and Crop Science, 1(6), 244-253

49) Sydenham, E., Shephard, G and Thiel, P. (1992) Liquid chromatographic determination of fumonisins B1, B2, and $\mathrm{B} 3$ in foods and feeds. Journal of AOAC International ,75: 313-318.

50) TBS (2010) Maize flour Specification. TZS 328:2010; ICS: 67.060. Tanzania Bureau of Standards: Dar es Salaam, Tanzania.

51) Towo E, S. U. and A. K. (2003). Phenolic compounds, Phytate, citric acid and the in-vitro iron accessibility of cowpeas, mug beans and four varieties of kidney beans. African Journal of Food, Agriculture Nutrition and Development , 3(1): 53-59.

52) Wheeler, E.I. and Ferrel, R.E. (1971). Methods for phytic acid determination in wheat and wheat fractions. Journal of Cereal Chemistry, 48: 312-320. 